Vol 3 No 2 (2020) 156-169 P-ISSN 2620-295 E-ISSN 2747-0490 DOI: 1047467/elmal.v3i2.52른

\title{
Pelaksanaan Promosi Jabatan Guna Mendorong Peningkatan Prestasi Kerja Karyawan PT. Berkah Handelar Qualitama
}

\author{
Farah Chalida Hanoum. T1, Ria Kusumaningrum² \\ 1IAI Nasional Laa Roiba Bogor \\ 2IAI Sahid Bogor \\ farahchalidah@laaroiba.ac.id ${ }^{1}$, rkusumaningrum@inais.ac.id ${ }^{2}$
}

\begin{abstract}
Every company that is established must have a goal that the company wants to achieve, namely seeking profit and improving employee social welfare. The company's success in achieving these goals depends on whether the company has quality human resources so that it is able to manage other resources properly. Therefore, human resources must be handled properly. Human resources are one of the biggest or most important assets for any company, be it a large company or a small company, therefore it is necessary to establish a division or division within a company that specifically handles these human resources, so that these human resources can be considered. specifically by the company. Promotion has an important role for every employee, because promotion means that the company has the trust and recognition of the ability and ability of the employee to hold a higher position. Thus promotion will generate motivation that encourages employees to actively participate in a company in order to get opportunities to advance, better social status, authority and responsibility as well as greater income for these employees.
\end{abstract}

Key words : human resources, Promotion, employee.

\section{PENDAHULUAN}

Setiap perusahaan yang didirikan pasti memiliki tujuan yang ingin dicapai perusahaan yaitu mencari keuntungan dan meningkatkan kesejahteraan sosial karyawan. Keberhasilan perusahaan dalam mencapai tujuan tersebut bergantung pada apakah perusahaan tersebut memiliki sumber daya manusia yang berkualitas sehingga mampu mengelola sumber daya lain dengan baik. Oleh karena itu sumber daya manusia harus ditangani dengan baik.

Sumber daya manusia merupakan salah satu aset terbesar atau terpenting bagi suatu perusahaan, baik itu perusahaan besar maupun perusahaan kecil, oleh karena itu perlu dibentuk suatu divisi atau divisi dalam suatu perusahaan yang secara khusus menangani sumber daya manusia tersebut, sehingga 
Vol 3 No 2 (2020) 156-169 P-ISSN 2620-295 E-ISSN 2747-0490 DOI: 1047467/elmal.v3i2.52프

sumber daya manusia tersebut dapat dipertimbangkan. khusus oleh perusahaan.

Promosi memiliki peran penting bagi setiap karyawan, karena promosi memiliki arti bahwa perusahaan memiliki kepercayaan dan pengakuan atas kemampuan dan kemampuan karyawan untuk menduduki jabatan yang lebih tinggi. Dengan demikian promosi akan menimbulkan motivasi yang mendorong karyawan untuk berpartisipasi aktif dalam suatu perusahaan guna mendapatkan kesempatan untuk maju, status sosial yang lebih baik, wewenang dan tanggung jawab serta pendapatan yang lebih besar bagi karyawan tersebut.

Dengan adanya kesempatan promosi jabatan maka karyawan akan mempunyai semangat dan gairah yang baik yang pada akhirnya akan meningkatkan prestasi kerja karyawan tersebut, tetapi seringkali karyawan merasa promosi yang diberikan tidak adil ataupun tidak puas dengan kebijakan promosi perusahaan sehingga hal ini akan berpengaruh pada prestasi karyawan.

\section{Perumusan Masalah}

Program promosi jabatan sangat penting baik bagi perusahaan dan juga bagi karyawan secara keseluruhan, yaitu dapat meningkatkan kualitas perusahaan karena karyawan akan berusaha meningkatkan prestasi kerjanya yang pada akhirnya dapat meningkatkan pula kualitas dari setiap perusahaan. Selain itu salah satu upaya perusahaan untuk bersaing dengan perusahaan lainnya adalah melalui pelaksanaan kebijaksanaan promosi jabatan, karena dengan promosi jabatan yang baik maka dapat menjadi daya tarik bagi calon tenaga kerja. Untuk itu maka perusahaan harus dapat melaksanakan kebijakan promosi jabatan dengan efektif dan efisien.

Bertitik tolak dari uraian diatas, maka dapat dirumuskan permasalahan yaitu : bagaimana pelaksanaan promosi jabatan pada PT Berkah Handelar Qualitama dalam mendorong peningkatan prestasi kerja karyawannya?

\section{Pembatasan Masalah}

Ruang lingkup pembahasan dibatasi hanya pada karyawan departemen operasional, variabel-variabel lain selain promosi jabatan yang mempengaruhi prestasi kerja dianggap konstan. 
Vol 3 No 2 (2020) 156-169 P-ISSN 2620-295 E-ISSN 2747-0490 DOI: 1047467/elmal.v3i2.52프

\section{Tujuan dan Kegunaan penelitian}

1. Memperoleh gambaran yang jelas mengenai kebijakan prmosi jabatan pada PT Berkah Handelar Qualitama

2. Mengetahui apakah pelaksanaan promosi jabatan pada PT Berkah Handelar Qualitama sudah berjalan secara efektif dan efisien

3. Mengetahui pengaruh promosi jabatan terhadap peningkatan prestasi kerja karyawan

4. Mengetahui hambatan-hambatan yang dihadapi PT. Berkah Handelar Qualitama

\section{Kegunaan Penelitian ini :}

1. Diharapkan dapat menjadi dasar pemikiran dan bahan masukan yang berguna sebagai dasar pertimbangan pengambilan keputusan dalam kebijakan promosi jabatan dalam upaya meningkatkan prestasi kerja karyawan.

2. Menambah pengetahuan bagi dunia pendidikan khususnya mengenai promosi jabatan dan sebagai bahan untuk studi perbandingan dalam rangka menerapkan teori ilmiah dengan kenyataan yang terjadi dalam perusahaan yaitu mengenai promosi jabatan.

\section{METODOLOGI PENELITIAN}

Dalam penelitian ini, digunakan Teknik pengumpulan data :

1. Studi kepustakaan

Dilakukan dengan cara membaca, serta mempelajari buku-buku yang berhubungan dengan masalah yang diteliti. Data yang diperoleh adalah data sekunder, yaitu data yang tidak berhubungan langsung dengan perusahaan. Data ini bersifat teoritis serta dapat dijadikan landasan dalam menganalisa subyek penelitian.

2. Riset lapangan (Field Research)

Yaitu metode yang dilakukam dengan mengunjungi perusahaan yang bersangkutan untuk mendapatkan data dan informasi yang diperlukan, seperti data produksi, daftar absensi karyawan, data yang diperoleh adalah data primer.

Riset ini dilakukan dengan wawancara (interview) dan daftar pertanyaan (Quistionnaire). 
Vol 3 No 2 (2020) 156-169 P-ISSN 2620-295 E-ISSN 2747-0490 DOI: 1047467/elmal.v3i2.52프

\section{TEKNIK ANALISIS DATA}

Analisis data yang digunakan adalah analisis hubungan A-simetris dimana suatu variable mempengaruhi variable lainnya.

Didalam penelitian ini terdapat variable promosi jabatan yang merupakan variable bebas (Independent Variable) dan variable prestasi kerja karyawan yang merupakan variable tidak bebas (dependent variable) karena prestasi kerja dipengaruhi oleh adanya pelaksanaan promosi jabatan.

\section{LANDASAN TEORI \\ PRESTASI KERJA}

Dalam menentukan promosi ada faktor-faktor yang perlu dipertimbangkan, diantaranya aadalah prestasi kerja karyawan. Penilaian prestasi kerja dapat memberikan informasi mengenai prestasi kerja karyawan yang selanjutnya digunakan sebagai dasar untuk promosi jabatan.

Handoko, dalam bukunya mengemukakan pengertian penilaian prestasi kerja adalah sebagai berikut :

Proses melalui mana organisasi-organisasi mengevaluasi atau menilai kerja karyawan. Dimana kegiatan ini dapat memperbaiki keputusan-keputusan personalia dan memberikan umpan balik kepada karyawan tentang pelaksanaan kerja mereka (2012: 135)

Kegiatanpenilaian kerja dapat memperbaiki keputusan-keputusan personalia dan memberikan umpan balik kepada para karyawannya tentang pelaksanaan kerja mereka.

Adapun kegunaan penilaian kerja bagi perusahaan menurut Rao antara lain :

1. Untuk memperoleh karyawan yang sesuai dengan tempat dan jabatannya (the right man on the right place)

2. Dapat mengetahui hasil dari tugas-tugas yang telah dilaksanakan oleh karyawan dibandingkan dengan standar yang diharapkan perusahaan.

3. Sebagai informasi bagi perusahaan untuk menentukan bila seorang karyawan perlu mendapatkan kenaikan gaji, dipromosikan atau diberhentikan.

\section{PROMOSI}




\section{Vol 3 No 2 (2020) 156-169 P-ISSN 2620-295 E-ISSN 2747-0490 DOI: $1047467 /$ elmal.v3i2.52르}

Salah satu dorongan seseorang bekerja pada suatu perusahaan adalah adanya kesempatan untuk maju. Sudh menjadi sifat dasar manusia untuk menjadi lebih baik dari keadaan sebelumnya. Oleh karena itu karyawan pada suatu perusahaan umumnya timbul keinginan untuk memperbaiki posisinya sehubungan dengan pekerjaannya.

Kesempatan untuk maju di dalam organisasi sering disebut sebagai promosi. Dengan demikian, promosi merupakan salah satu alat yang dapat digunakan untuk memotivasi karyawan dalam rangka meningkatkan prestasi, jika promosi tersebut diberikan secara adil dan obyektif.

Kegiatan promosi merupakan salah satu kegiatan yang penting baik bagi perusahaan maupun bagi karyawannya. Kegiatan promosi merupukan salah satu bentuk arus perpindahan karyawan di dalam perusahaan (internal movement), yaitu bagian dari kebijakan pengadaan karyawan.

Istilah promosi banyak digunakan dalam berbagai aspek manajemen sumber daya manusia. Menurut Heidjrachman dan Husnan :

Promosi berarti perpindahan dari suatu jabatan ke jabatan lain yang mempunyai status dan tanggungjawab yang lebih yinggi (2000:111).

\section{HUBUNGAN PROMOSI JABATAN DENGAN PRESTASI KERJA KARYAWAN}

Dengan adanya pelaksanaan promosi jabatan yang baik dan adil, maka dapat mendorong karyawan untuk bekerja dengan lebih baik untuk meningkatkan prestasi kerja mereka agar mereka dapt memenuhi syarat-syarat promosi yang ditetapkan oleh perusahaan, karena promosi merupakan sesuatu yang selalu di idam-idamkan oleh setiap karyawan. Keinginan untuk mendapatkan promosi jabatan pada setiap karyawan sangatlah besar hal ini disebabkan karena setiap manusia pasti mempunyai ambisi, oleh karena ambisi inilah yang dapat mendorong karyawan untuk bekerja dengan lebih baik untuk memenuhi syarat-syarat promosi yang telah ditetapkan oleh perusahaan.

\section{ANALISIS DAN PEMBAHASAN}

\section{Latar Belakang Diadakannya Promosi Jabatan}

Salah satu upaya yang dilaksanakan oleh PT Berkah Handelar Qualitama agar dapat memperbaiki serta mendorong karyawan untuk meningkatkan prestasi kerja mereka adalah dengan mengadakan promosi jabatan. Promosi jabatan yang dilaksanakan oleh perusahaan dapat berguna untuk memberi dorongan kepada karyawan untuk bekerja dengan lebih baik 


\section{Vol 3 No 2 (2020) 156-169 P-ISSN 2620-295 E-ISSN 2747-0490 DOI: 1047467/elmal.v3i2.52프}

lagi. Dengan semakin berkembang perusahaan maka dibutuhkan karyawan yang memiliki kualitas yang sesuai dengan yang diinginkan perusahaan. Suatu usaha atau bisnis akan dapat berkembang dengan baik apabila para karyawan memiliki lingkungan kerja yang kompak dan antara perusahaan dengan karyawan saling berinteraksi secara positif, artinya perusahaan dan karyawan tidak saling merugikan dalam mencapai tujuannya masing-masing.

Promosi jabatan selain berguna untuk kepentingan perusahaan, juga bermanfaat bagi karyawan. Karena dengan adanya promosi jabatan, karyawan akan merasa dihargai hasil kerjanya oleh atasannya Dalam usaha untuk melaksanakan promosi jabatan perusahaan perlu melakukan penilaian prestasi kerja karyawannya untuk mendapatkan karyawan yang cocok untuk suatu jabatan tertentu.

\section{Pelaksanaan Promosi Jabatan}

Di dalam menjalankan kegiatan usahanya, perusahaan selalu memberitahukan terlebih dahulu kepada seluruh karyawannya mongenai tujuan yang ingin dicapai oleh perusahaan.

perusahaan. Selanjutnya perusahaan memberikan kebebasan, kepercayaan, serta tanggung-jawab kepada karyawannya untuk bekerja sebaik mungkin demi tercapainya tujuan perusahaan tersebut, Walaupun demikian, hal ini tidak berarti bahwa perusahaan tidak memantau, menilai, serta mengevaluasi setiap hasil pekerjaan dari para karyawannya Perusahaan secara berkala, terus memantau, menilai serta mengadakan evaluasi terhadap setiap hasil kerja, sikap kerja dan potensi dari setiap karyawalnya Pihak manajemen perusahaan PT Berkah Handelar Qualitama menyadari sepenuhnya bahwa karyawan adalah salah satu kekayaan (asset) utama perusahaan yang perlu selalu dibina dan dipelihara dengan baik. Karena peningkatan pengetahuan, ketrampilan dan kemampuan serta sikap karyawan di dalam melakukan pekerjanya akan berdampak positif terhadap kemajuan dan perkembangan perusahaan.Untuk menunjang hal-hal tersebut di atas, perusahaan memerlukan adanya suatu sistem penilaian yang diperuntukan bagi karyawannya Sistem penilaian karyawan tersebut dikenal dengan penilaian prestasi kerja Dalam pelaksanaan penilaian prestasi kerja karyawan pada PT Berkah Handelar Qualitama, terdapat unsur-unsur penting yang menunjang pelaksanaan penilaian prestasi kerja karyawan, yaitu :

Metode penilaian prestasi kerja yang digunakan.

Dalam prosedur penilaian prestasi kerja karyawan pada PT Berkah Handelar Qualitama, perusahaan menggunakan Metode Rating Scale, yaitu suatu 
Vol 3 No 2 (2020) 156-169 P-ISSN 2620-295 E-ISSN 2747-0490 DOI: 1047467/elmal.v3i2.52프

metode penilaian dimana kepada pihak-pihak yang berwenang untuk melakukan penilaian akan dibagikan formular penilaian yang berisikan berbagai kriteria penilaian yang merupakan unsur-unsur penting dari pekerjaan yang sebagai standar penilaian. Untuk selanjutnya, formulir tersebut diisi berdasarkan pendapat dari penilai, dengan membandingkan hasil pekerjaan seorang karyawan yang dinilai dengan kriteria-kriteria yang dianggap penting bagi pelaksanaan kerja tersebut.

1. Pendapat-pendapat dari penilai dapat diberikan dalan nilai-nilai munerik yaitu dari 1 sampai dengan S, agar memungkinkan skor rata-rata dihitung dan diperbandingkan diantara para karyawan. Masing-masing nilai memberikan gambaran kemampuan karyawan, yaitu :

a. Nilai 1 : Menunjukkan apa yang dilakukan oleh karyawan jauh dari yang diharapkan

atau distandarkan perusahaan

b. Nilai 2: Menunjukkan apa yang dilakukan oleh karyawan mendekati standar

perusahaan.

c. Nilai 3 : Menunjukkan apa yang dilakukan oleh karyawan sesuai dengan standar

perusahaan.

d. Nilai 4 : Menunjukkan apa yang dilakukan oleh karyawan kadangkadang melebihi

standar perusahaan

e. Nilai 5: Menunjukkan apa yang dilakukan oleh karyawan selalu melebihi standar

perusahaan.

2. Kriteria penilaian yang ditetapkan.

PT Berkah Handelar Qualitama menilai prestasi kerja karyawannya berdasarkan kriteria-

kriteria penilaian sebagai berikut :

a Kerajinan.

Yaitu sikap yang menunjukkan bahwa seorang karyawan dalan bekerja dapat datang 
Vol 3 No 2 (2020) 156-169 P-ISSN 2620-295 E-ISSN 2747-0490 DOI: $1047467 /$ elmal.v3i2.52른

tepat waktu.

b. Kerapihan kerja

Yaitu hasil dari pekerjaan yang dinilai atas kerapihannya.

c. Ketelitian kerja

Yaitu kemampuan didalam melaksanakan pekerjaan dengan teliti.

d. Kerjasama

Yaitu kemampuan dan kesediaan untuk bekerja sama secara efektif dan harmonis dalam lingkungan kerja. . Tanggung-jawab. Yaitu sikap yang selalu berusaha menyelesaikan tugasnya dengan baik, tepat pada waktunya.

f. Ketrampilan kerja.

Yaitu kemampuan di dalam melaksanakan dan menyelesaikan tugas yang diberikan.

g. Kepedulian.

Yaitu sikap yang menunjukkan kemauan untuk mengetahui hal-hal lain yang berhubungan dengan tugas dan pekerjaannya.

h. Cara Kerja

Yaitu berkaitan dengan ketrampilan kerja dimana ketrampilan kerja seorang karyawan dapat terlihat dari bagaimana ia bekerja menyelesaikan pekerjannya.

i. Kewibawaaan.

Yaitu unsur yang dilihat dari kemampuan dalam diri seorang karyawan di dalam mengendalikan sikap dan perilakunya.

J. Kemampuan menangkap perintah.

Yaitu berkaitan dengan kemampuan seorang karyawan di dalam menerjemahkan perintah yang diberikan oleh atasan untuk mengerjakan suatu pekerjaan.

Sedangkan standar penilaian prestasi kerja karyawan yang digunakan, dapat dijelaskan sebagai berikut 
Vol 3 No 2 (2020) 156-169 P-ISSN 2620-295 E-ISSN 2747-0490 DOI: 1047467/elmal.v3i2.52프

Standar Penilaian Prestasi Kerja Karyawan PT Berkah Handelar Qualitama

$\begin{array}{lll}\text { Nilai } & \text { Huruf } & \text { Kategori } \\ 5 & \text { A } & \text { Sangat Baik } \\ 4 & \text { B } & \text { Baik } \\ 3 & \text { C } & \text { Cukup } \\ 2 & \text { D } & \text { Kurang } \\ 1 & \text { E } & \text { Sangat Kurang }\end{array}$

Kemudian setelah masing-masing kriteria penilaian tersebut sudah dinilai, maka untuk selanjutnya akan dihitung nilainya berdasarkan nilai rata-rata dari jumlah kriteria yang dipakai sebagai standar penilaian, yaitu dengan rumusan sebagai berikut :

$$
\begin{array}{r}
\text { Nilai }=\text { Jumlah dari Seluruh Kriteria Penilaian } \\
\quad \div \text { banyaknya Kriteria Penilaian }
\end{array}
$$

Nilai inilah yang kemudian digunakan oleh perusahaan sebagai dasar untuk menentukan seorang karyawan memiliki prestasi kerja, sangat baik, baik, cukup, kurang atau mungkin sangat kurang.

Sedangkan yang berhak menilai prestasi kerja karyawan adalah atasan langsung dari karyawan yang dinilai tersebut, dengan pengawasan dari departemen sumber daya manusia. Jadi departemen sumber daya manusia hanya menunggu hasil dari penilaian yang dilakukan oleh setiap departemen, untuk seterusnya memeriksa berkas-berkas laporannya. Dalam fomuulir penilaian tersebut juga disediakan kolom saran bagi penilai dalam mengemukakan kesimpulan dan pendapatnya secara umum terhadap karyawan yang dinilai sehingga dapat menjadikan masukan yang berharga bagi departemen sumber daya manusia.

2. Waktu pelaksanaan penilaian prestasi kerja.

PT. Berkah Handelar Qualitama mengadakan penilaian prestasi kerja terhadap karyawan operasionalnya setiap 3| ( tiga) bulan sekali dalam setahun. 


\section{Vol 3 No 2 (2020) 156-169 P-ISSN 2620-295 E-ISSN 2747-0490 DOI: 1047467/elmal.v3i2.52프}

Berdasarkan perhitungan tingkat absensi karyawan yang tidak dipromosikan mengalami penurunan dari tahun ke tahun, yaitu dengan ratarata tingkat abensi per tahun adalah 1,27\%. Tingkat absensi karyawan yang tidak dipromosikan ini memperlihatkan keadaan yang baik karena setiap tahunnya mengalami penurunan, tetapi bila dibandingkan dengan tingkat absensi karyawan yang dipromosikan yaitu dengan rata-rata $0,91 \%$ masih terlihat bahwa karyawan yang dipromosikan menunjukkan hasil yang lebih baik. Walaupun demikian hasil ini menunjukkan bahwa semangat kerja karyawan tetap ada.

Dari ke-2 kriteria yang ditetapkan di dalam mengukur keberhasilan promosi jabatan dalam upaya meningkatkan prestasi kerja ternyata mendapatkan hasil yang positif yaitu tingkat produktivitas karyawan yang dipromosikan semakia meningkat dan tingkat absensi karyawan yang dipromosikan semakin menurun.

Berdasarkan analisis data diatas, maka dapat dikatakan bahwa pelaksanaan promosi jabatan di perusahaan sangat berhubungan erat dengan prestasi kerja yaitu dilihat dari tingkat produktivitas dan tingkat absensi dimana hal tersebut amat menunjang kelancaran perkembangan perusahaan khususnya dalam meningkatkan produktivitas perusahaan. Untuk itu barus terus diupayakan agar pelaksanaan promosi jabatan dapd terus berjalan dengan baik, karena pelaksanaan promosi jabatan pada PT Berkah Handelar Qualitama mampu meningkatkan prestasi kerja karyawannya.

D. Kendala-Kendala Yang Dihadapi Perusahaan Dalam Melaksanakan Promosi

Jabatan Dan Pemecahannya Berdasarkan dari pembahasan mengenai promosi jabatan yang dilaksanakan oleti perusahaan, menunjukkan adanya kelemahan tertentu. Keadaan ini sudah tentu tidak terjadi begitu saja, tetapi banyak faktor yang perlu dipertimbangkan lebih lanjut. Kendala yang dihadapi PT Berkah Handelar Qualitama:

1. Karyawan tidak puas dengan basil pelaksanaan promosi jabatan, misalnya seorang karyawan tidak dipromosikan tetapi ia merasa dirinya telah memeoubi persyaratan untuk dipromosikan. Hal ini dapat terjadi karena sering terjadinya dua atau lebih karyawan yang memiliki nilai penilaian prestasi yang sama, sehingga menyebabkan apabila salah satu dari dua atau lebih karyawan ini dipromosikan swdangkan yang lainnya tidak maka dapat menyebabkan timbulnya rasa kecewa pada karyawan yang tidak dipromosikan dan juga mereka akan bertanya-tanya mengapa mereka tidak dipromosikan juga, mengingat bahwa semua persyaratan untuk promosi sudah mereka penuhi. 


\section{Vol 3 No 2 (2020) 156-169 P-ISSN 2620-295 E-ISSN 2747-0490 DOI: 1047467/elmal.v3i2.52프}

2. Penilaian prestasi kerja pada perusahaan dibebankan pada kepala bagian Dalam menilai prestasi kerja karyawan, perusahaan mesih menunjukkan kelemahar kelemahan dan penyimpangan-penyimpangan yang dikenal sebagai kesalahan- kesalahan manusiawi ( human errors ) terutama antuk pemiaan kriteria-kriteria seperti kerjasama, kepedulian, dan kewibawaan dimana kriteria-kriterta tersebut tidak dapat dinilai berdasarkan pada kuantitasnya akan tetapi pada kualitasnya sehingga dapat mengakibatkan terjadinya kesalahan dalam penilaian, Penilaian yang kurang baik ini dapat menimbulkan turunnya semangat kerja karyawan dapat menghambat pengembangan kemampuan dan motivasi yang terdapat pada karyawan yang bersangkutan. Apabila penilaian karyawan didasarkan atas perasaan tertentu maka hal ini akan berpengaruh tidak baik bagi karyawan yang memiliki potensi untuk berprestasi, karena hal ini dapat menghambat perkembangan karir karyawan tersebut.

Pemecahan yang dapat dilakukan terhadap masing-masing kendala di atas, adalah sebagai berikut:

1. Memberikan konsultasi terhadap karyawan yang belum dapat dipromosikan karena dengan demikian karyawan akan menyadari bahwa dirinya tetup diperhatikan, wlun itu perusahaan akan memberikan kenaikan gaji bagi karyawan berebut sehingga tidak menurunkan semangat kerja.

2. Di dalam mengatasi penilaian prestasi kerja yang lanya dilakukan oleh kepala bagian maka perusahaan dapat membentuk suatu tim penilai khusus gun menghindari unsur subyektivitas dan mereka perlu dibina, diawasi serta diberikan pengarahan pengarahan agar penilaian mereka lebih obyektif. Sehingga kesalahan kesalahan manusiawi ( human errors ) dapat diminimalkan sedapat mungkin.

\section{KESIMPULAN DAN SARAN}

\section{Kesimpulan}

1. Pelaksanaan promosi jabatan pada PT Berkah Handelar Qualitama didasarkan pada 10 kriteria yang ditetapkan oleh perusahaan. Kriteriakriteria tersebut mewakili aktivitas karyawan dalam perusahaan Setiap karyawan akan dinilai berdasarkan kriteria kriteria tersebut.

2. Dalam melaksanakan penilaian prestasi kerja karyawannya, perusahaan menggunakan metode Rating Scale, yaitu metode penilaian dimana kepada pihak-pihak yang berwenang untuk melakukan penilaian akan dibagikan formulir penilaian yang berisikan berbagai 


\section{Vol 3 No 2 (2020) 156-169 P-ISSN 2620-295 E-ISSN 2747-0490 DOI: 1047467/elmal.v3i2.52프}

kriteria penilaian yang merupakan unsur-unsur penting dari pekerjaan, yang digunakan sebagai standar penilaian.

3. Berdasarkan evaluasi pengaruh pelaksanaan promosi jabatan terhadap peningkatan prestasi kerja karyawan menunjukkan hasil yang baik yaitu terlihat dari :

a. Tingkat produktivitas kerja karyawan yang dipromosikan mengalami peningkatan dari tahun ke tahun dengan rata-rata sebesar 13,75\% dan produktivitas kerja karyawan dengan penilaian sangat baik yang belum dapat dipromosikan menunjukkan peningkatan produktivitasnya dengan rata-rata kenaikan sebesar 10,91\%

b. Tingkat absensi karyawan yang dipromosikan semakin menurun yaitu rata-rata

per tahunnya adalah 0,9196 dan untuk karyawan dengan penilaian sangat baik yang pelum dapat dipromosikan juga mengalami penurunan yaitu dengan rata-rata sebesar 12796.

4. Kendala-kendala yang dihadapi perusahaan dalam melaksanakan promosi jabatan adalah bahwa karyawan tidak puas dengan hasil pelaksanaan promosi jabatan, karena karyawan merasa dirinya telah memenuhi persyaratan untuk dipromosikan tetapi ia tidak dipromosikan. Selain itu, penilaian prestasi kerja yang menjadi dasar di dalam penentuan promosi dibebankan pada kepala bagian, sehingga penilaiannya cenderung bersifat subyektif.

\section{Saran}

1. Untuk mengatasi rasa tidak puas karyawan maka perlu diadakan konsultasi dengan karyawan dengan menjelaskan bahwa keterbatasan perusahaan sehingga tidak semua karyawan dapat dipromosikan sehingga dapat diketahui bahwa perusahaan tetap memperhatikan karyawannya.

2. Pelaksanaan penilaian prestasi kerja yang dibebankan kepada kepala bagian cenderung bersifat subyektif oleb karena itu perusahaan dapat menghindarinya dengan membentuk suatu tim penilai khusus sehingga hasil penilaian dapat lebih Obyektif dan untuk itu tim penilai khusus tersebut perlu dibina, diawasi serta diberikan pengarahan-pengarahan.

3. Perusahaan scharusnya menentukan satu atau dua dari sepuluh kriteria yang ada sebagai kriteria utama, sehingga bila terdapat dua orang karyawan yang memiliki nilai rata-rata yang sama maka perusahaan hanya melihat diantara kedua karyawan brsebut karyawan mana yang memiliki nilai 
Vol 3 No 2 (2020) 156-169 P-ISSN 2620-295 E-ISSN 2747-0490 DOI: $1047467 /$ elmal.v3i2.52르

tertinggi pada kriteria utamanya sehingga kendala yang dihadapi perusahaan dapat teratasi.

\section{DAFTAR PUSTAKA}

Dessler, Gary (2004). Manajemen Sumber Dnya Manusia, Edisi Ketiga, Jakarta : Penerbit Erlangga.

pe Cenzo, David A. dan Robbin, Stephen P (1996). Human Resource Management Fifth Edition, New York : John Wiley \& Sons, Inc.

Flippo, F Edwin B (2013), Personel Management (Manajemen Personalia), Edisi. VII. Jilid II, Terjemahan Alponso S, Erlangga, Jakarta.

Handoko, T. Hani (2012). M..: : 'emen Personalia Dan Sumber D: : Manusia, Edisi Kedua, Yogyakarta : Penerbit BPFE Universitas Gajah Mada.

Hasibuan, Malayu, S.P., Drs, (2003). Manajemen Sumber Daya Manusia : Dasar Dan Kunci Keberhasilan, Edisi Kedua, Jakarta : Penerbit C.V. Haji Masagung.

Heidjrachman, Ranupandojo (2000). Manajemen Personalia, Edisi Keempat, Yogyakarta : Penerbit BPFE Universitas Gajah Mada.

Moenir, A.S., Drs, (2001). Pendekatan Manusiawi Dan Organisasi Terhadap Pembinaan Karyawan, Cetakan Ketigara, Jakarta : Penerbit Gunung Agung.

Rao, T.V. (1992). Penilaian Prestasi Kerja: Teori Dan Praktek, Seri Manajemen No. 125, Cetakan Kedua, Jakarta : PT. Karya Unipres.

Ravianto, J (1990). Produktivitas Dan Mutu Kehidupan, Edisi Ketiga, Jakarta : Lembaga Sarana Informasi Usaha Dan Produtivitas ( SIUP). 
Vol 3 No 2 (2020) 156-169 P-ISSN 2620-295 E-ISSN 2747-0490 D0I: 1047467/elmal.v3i2.52므

Werther, Wiliiam B. dan Davis, Keith (2005). Personnel Management And Human Resources, Fourth Edition, Singapore : McGraw Hill. 